\title{
ISTORIA ETICII MEDICALE EUROPENE ÎN A DOUA JUMĂTATE A SECOLULUI XX
}

\author{
dr. Horber Orsolya, dr. Zilahi Karoly, medici primari medicina familiei, Societate Civila \\ Medicala Praxis Dr. Horber-Dr. Zilahi
}

La sfârşitul celui de-al Doilea Război Mondial a avut loc o schimbare semnificativă a structurii şi orientării societăților europene.

Deşi moştenirea războiului a fost identică pentru toată Europa, drumul ales sau impus pentru schimbarea țărilor occidentale, respectiv estice este diferit. „Cortina de fier” căzută pe continent, izolând capitale vechi ca Varşovia, Berlin, Praga, Budapesta, Bucureşti şi Sofia, marchează zonele de influență, sfera sovietică cuprinzând o mare parte din teritoriul Europei Centrale şi de Est. Drumul spre rezolvarea conflictelor exterioare şi interioare va fi lung şi anevoios şi în multe cazuri nu va aduce catarsisul aşteptat, întrebările rămânând deschise.

\section{Societatea europeană occidentală şi bioetica}

Ori de partea victorioşilor, ori de partea înfrânților, țările Europei au ieşit grav afectate din cel de-al Doilea Război Mondial. Divizat şi sărăcit, vechiul continent caută răspunsuri la ororile războiului, la teroare, lagăre de concentrare, Holocaust. Societatea postbelică se schimbă inevitabil. Oraşe în ruine, infrastructura distrusă, restricții economice şi alimentare, caracterizează țările proaspat ieşite din război. Reconstrucția este grea şi lungă, dar în condițiile ajutorului american se produc „miracole economice” în Europa Occidentală.

Dezvoltarea economică însă nu rezolvă problemele morale ale societății. Europeanul anului 1945 este individul „nou, existentialist” (Sartre). Omul postbelic rămane singur, fără scuze, „condamnat la libertate”. Libertatea existentialistă ca formă nouă a umanismului va fi atractivă pentru generația nouă: frustrată, singuratică, deziluzionată, austeră, agresivă, căutând răspunsuri la întrebari deschise sau ascunse ale trecutului.

În acest context are loc procesul de la Nurnberg, primul proces modern internațional. Rolul medicilor nazişti în Holocaust va fi discutat în Procesul Medicilor început la 9 decembrie 1946. Conştiința societăților europene nu va fi împăcată, nu toți vinovații vor fi învinuiți în proces, dar crimele „sunt aşa de oribile, încât nu le putem ignora, pentru că repetarea lor ar duce la desființarea civilizatiei noastre" (Robert H. Jackson, procurorul procesului). Pe baza materialului Procesului Medicilor apare Codul de la Nurnberg cu cele zece puncte privind experimentele umane, care desfiintează experimentul fără consimțământul voluntar al participanților.

Căutând răspunsuri la problemele etice, la atitudinea fals-ştiintifică a medicilor din timpul războiului, se conturează o nouă ştiință: bioetica. În acest sens adoptarea Declarației Univerale a Drepturilor Omului (ONU, decembrie 1948) este un prim pas. Declarația de la Geneva adoptată în acelaşi an de Asociația Medicală Mondiala (WMA) subliniază rolul nediscriminării în relația medic pacient, respectiv obigativitatea depunerii unui jurământ medical înaintea începerii activităţii medicale. 


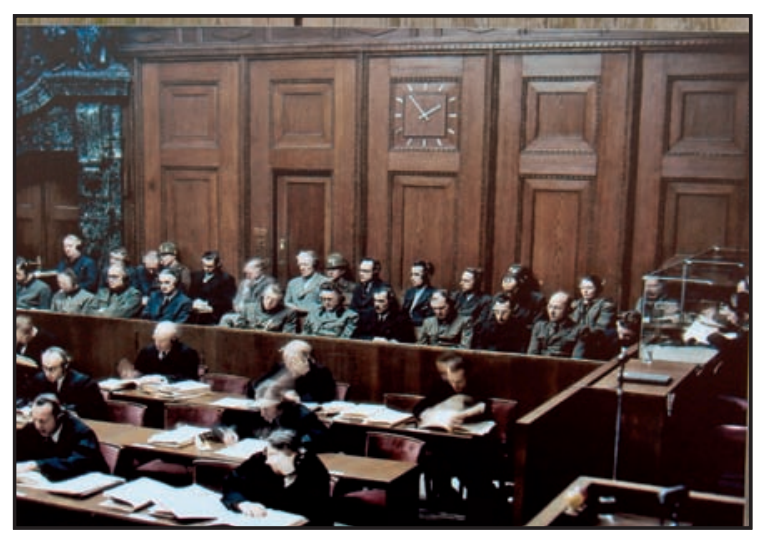

Medicul din a doua jumătate a secolului XX răspunde greu provocărilor societății în schimbare: dezvoltare tehnologică, specializare accentuată, apariția mai multor întrebări de etică medicală (problema eutanasiei, a cercetării pe subiecți umani, transplant de organe).

Problemele complexe ştiințifice necesită cunoştințe ale ştiințelor naturii, dar şi însuşirea ştiințelor umaniste: istorice, etice, filozofice şi juridice.

În activitatea sa medicul va fi ajutat de legi şi coduri de conduită. Istoria codurilor de etică medicală continuă şi după 1948:

-Declarația de la Helsinki, adoptată la a 18-a Adunare generală a Asociației Medicale Mondiale, în iunie 1964, cu amendamentele ulterioare; vizează cercetarea pe subiecți umani

-Declaraţia de la Tokio, 1975; directive şi norme pentru înlăturarea torturii şi alte tratamente inumane şi degradante

-Declarația de la Oslo, 1970, despre avortul terapeutic

-Declarația de la Singapore, 1984, privind maltratarea şi abandonul minorilor.

Procesul spre unificare a țărilor occidentale va aduce schimbări şi în viziunea lor asupra sănătăţii publice şi a comunității. După numai 9 ani de la Tratatul de la Roma se nasc documentele cooperării sanitare medicale europene privind informarea şi controlul serviciilor medicale şi farmaceutice între statele membre.

\section{De la regimul totalitar nazist la regimul totalitar comunist}

Dacă în Europa Occidentală dezvoltarea naturală şi confruntarea cu trecutul vor duce la valori bine definite, în Europa de Est schimbările sunt mult mai lente, trecând printr-o perioadă totalitară nouă. Societatea est-europeană postbelică este şi ea puternic afectată. Structura societății a suferit mai mari schimbări decât cea occidentală: o mare parte din intelectualitate (nu prea numeroasă nici înaintea războiului) căzând victimă Holocaustului.

Populația săracă, cu o educație precară, neavând o structură socială bine organizată, devine receptivă la ideile propagandistice comuniste. Colectivizarea forțată, preponderența industriei grele în dauna industriei uşoare producătoare de bunuri de consum, transformă societatea tradițională rurală. Guvernul comunist încearcă să distrugă diferențele între locuitorii satului şi oraşului, prin aceasta „realizând” egalitatea şi dreptatea promisă de fondatorii comunismului. Sistematizarea şi reorganizarea teritorială transformă habitatul rural, dar şi cel urban. Se formează astfel aceea „societate fără clase” (Arendt), în care masele şi nu clasele vor fi guvernate şi de la care se cere loialitate totală şi necondiționată.

Democrația populară, ca parte a ideologiei comuniste, prevede asistența medicală gratuită pentru toți locuitorii țării. În vederea realizării acestui obiectiv, statul comunist avea nevoie de mai mulți medici şi mai multe instituții medicale corespunzătoare. Astfel numărul studenților medicinişti a crescut semnificativ, formarea, educarea, dar şi admiterea lor în facultăţi este supravegheată de Partidul Comunist. Membrii vechii burghezii, a partidelor politice istorice, chiar şi a țăranimii bogate sunt excluşi. Propaganda politică devine disciplină universitară mai ales în epoca stalinistă. 
Spitalele, maternitățile, policlinicile sunt naționalizate prin Decretul Marii Adunări Naționale (3 noiembrie 1948). Cabinetele medicale private sunt suprimate, mai târziu eliminate. În februarie 1953 se începe organizarea circumscripțiilor sanitare rurale care asigurau asistență medicală gratuită populației arondate. A termina o facultate de medicină şi a primi o diplomă de medic a însemnat a primi direct un loc sigur în aceste circumscripții, deseori izolate, cu populație săracă şi slab educată. Organizarea circumscripțiilor medicale şi acordarea asistenței medicale gratuite a reprezentat un mare pas pentru o populație care nu a avut niciodată acces la asistența sanitară corespunzătoare, însă pentru medici prețul va fi prea ridicat.

După discursul lui Hrusciov din 25 februarie 1956 la Moscova, elementele cultului personalității dispar, dar propaganda rămâne. Repartizarea medicilor continuă, deseori la sute de kilometri de domiciliu, procesul fiind organizat de medici-funcȚionari Şi supravegheat de Partid.

Ascensiunea politică şi dictatura lui Nicolae Ceauşescu este sinonimă cu dispariţia totală a relației normale medic-pacient. Controalele administrative permanente, politica de demografie forțată (Decretul 770/1966), izolarea progresivă a medicului, caracterizează o asistență medicală precară.

Programul impus obligator, asistența medicală permanentă de 24 ore, ocupă tot timpul liber al medicului, lipseşte contactul cu alți medici şi cu lumea medicală ştiințifică occidentală. ”Mişcările totalitare sunt organizații de masă ale unor indivizi atomizați şi izolați” (Hannah Arendt).

Penuria dictaturii anilor 80 înseamnă cabinete şi spitale insalubre, aparate medicale inadecvate. $\mathrm{Nu}$ se poate vorbi de etică medicală când drepturile medicilor şi ale pacienților sunt îngrădite şi încălcate şi când principiul lui Hippocrate „primum non nocere” nu poate fi aplicat.

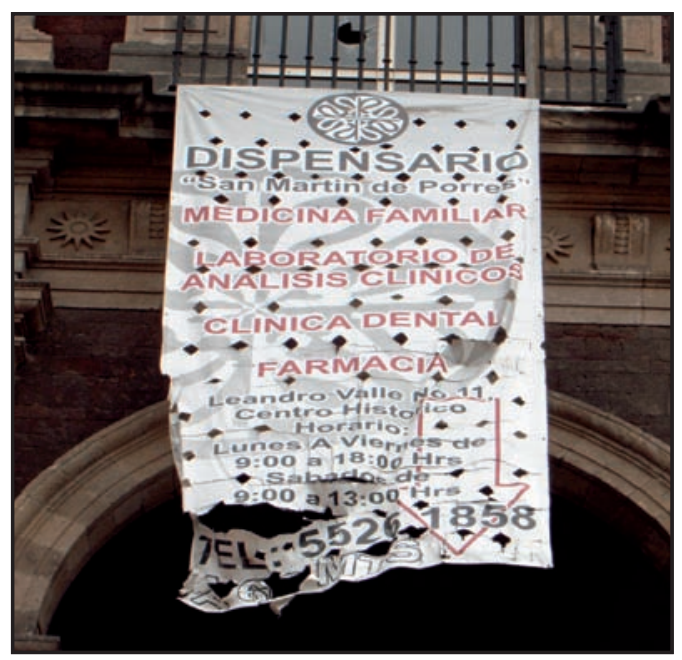

\section{Etica medicală în perioada comunistă?... în câteva cuvinte}

Lipsa încrederii reciproce în relația medic-pacient; izolare şi lipsa confraternității; incapacitate de a lucra profesional prin restricții administrative şi economice; nerespectarea drepturilor şi a vieții private a medicului, dar şi a pacientului; incapacitatea respectării principiului de a face bine şi de a promova binele; alterarea imaginii şi integrității medicului; nerespectarea secretului profesional prin obligarea medicului de a dezvălui date cu caracter personal ale pacientului. În concluzie: implicarea regimului şi a statului totalitar în relaţia medic-pacient.

Calea spre adevăratele valori europene este lungă şi dificilă după 1989. Trăirea şi perpetuarea vechilor mentalități, necunoaşterea modelelor europene sau adaptarea lor spontană şi prea rapidă la realități locale, îngreunează construirea unui nou sistem.

Cunoaşterea istoriei medicinei din această perioadă ne ajută să regândim toate schimbările majore dintr-o perspectivă obiectivă şi critică.

Confruntarea cu trecutul comunist este o datorie morală a societății medicale contemporane. 


\section{Bibliografie}

1. Arendt H.: Originile totalitarismului, Editura Humanitas, Bucureşti, 2006

2. Carpentier J., Lebrun F.: Istoria Europei, Editura Humanitas, Bucuresti, 2006

3. Horber O., Zilahi K.: L'implication de l'Etat communiste roumain dans la relation medecin-patient dans la deuxieme moitie du XXe siecle. L'ethique medicale entre conviction et contrainte, Analecta Historico Medica I, Memorias 41 Congreso Internacional de Historia de la Medicina, 7-12 sept.2008, Mexico-Puebla

4. Ioan B., Gavrilovici C., Astarastoae V.: Bioetica, cazuri celebre, Editura Junimea, Iaşi, 2005

5. Johnson P: Intelectualii, Editura Humanitas, Bucureşti, 2006

6. Soulet J-F: Istoria comparată a statelor comuniste, Editura Polirom, Iasi, 1998

7. Zilahi K., Horber O.: Naşterea bioeticii-Context istoric, Conexiuni medicale, nr.3-4, octombrie 2006, Satu Mare 